\title{
SUMARY
}

Discussed are the taxunomy of the Scleria arundinacea-latifolia complex, mitis, and S. myricocarpa, all controversial and waspriad taxa in thrical Astrica. Scleria cerradicola is described as new in the section Himenolytrum and a range extension of a rare species, Scleria neogranatensis, is woted.

As part of a series of occasional papers on the Cyperaceae of tropical America (Koyana 1969, 1984), the present paper reports the results of taxonomic studies made on the recent collections of the genus Scleria. Among the recent collections which 1 have examined, the specimens from Brazilian Planalto gathered by H. S. Irwin and those of G. T. Prance and his associates miade under the auspices of Projeto flora have been specialiy useful in solving problems presented by wide spread and variable taxa such as the Scleria arundinacea-latifolia complex, S. mitis, and S. myricocarpa and its close allies.

1. Scieria neogranatensis C. B. Glarke, kew Bull. Add. Ser. 8: 62. 1908. Type: Colom bia, la Paila, Holton 108 (K, lectotype; NY, isotype); [without details] 1,000 m, Triana 435 (K, syntype).

Distribution. Colombia and adjoining western Amazonian basin. Marshy places and thickets. Specimens examined. COLOMBIA. Antioquia: Fredonia, $1850 \mathrm{~m}$ alt., Archer 555 (NY. US) ; vicinity of Medellin, Toro 595 (NY): Santiago, vic, of Medellin, Toro 589 (NY). Santa Marta: [without further details], H. H. Smith 2199 (NY). PERU. Maynas: Loreto, Pucaurquillo to Pevas, $100 \mathrm{~m}$ alt., Ayala 2944 (NY). BRAzIL. Acre: Mun. Sena Madureira, trail to Rio laco from $\mathrm{km}$. 7. road between Sena Madureira to Rio Bran co, Prance et al. 7727 (INPA, K, NY, US).

In section Schizolepis, this species is distinct in having small achenes which are only 1.0 to $1.3 \mathrm{~mm}$ across while other species in the section possess achenes which

(*) Part II published in Bot. Mag. Tokyo 97: 413-421. 1984.

$(*$ the New York Botanical Garden, Bronx, N. Y. 10458, L.S.A. 
are 2 to 3 man across. Determination of recent collections marks substantial extension of this rare species into northeastern Peru and western Brazil.

2. Scleria latifolia Swartz, Prodr. Veg. Ind. Occid. 18. 1788. Type: Jamica, Swartz s. n. (s, holotype; NY, photo).

2a. subsp. latifolia -- Carex latifolia (Swartz) Gmelin, Syst. Nat. 2: 138.1791. Schizolepis latifolia (Kunth) Nees in Martius, Fl. Brasil. 2(1); 186.1842. Scleria nervosa Wikström, Vet. Akad. Handl. 1827 (=0Fversiget Guadel. Fl.): 1828. Type: Guadeloupe, Forsstrom (S).

Scleria sylvestris Kunth, Enum. PI. 2: 346. 1837. Type: Perū, Huanuco, "in sylvis ad Cuchero", Poeppig (B).... Schizolepis sylvestris (Kunth) Nees in Martius, F1. Brasil. 2(1): 223-224. 1842. Ut "silvestris" in indice.

Scleria arundinacea Kunth, Enum. Pl. 2: 347. 1837. Type: "S. latifolia Sieb. Hb. Agrostotheca No. 99 " (B, photo in NY) from "Nova Holiandial" apparently by error. Core (1936) assumes that the type is possibly from Martinique.

Schizolepis arundinacea (Kunth) Palla, Denkschr. Akad. Wien 79: 196. 1908.

Scleria latifolia Swartz var. arundinacea (Kunth) H. Pfeiffer in Fedde, Repert. Sp. Nov. 52: 171.1943.

Scleria cyanocarpa Kunth, Enum. P1. 2: 347. 1837. Type: Brazilia meridionalis, Sellow (B, photo in NY).

Scleria olyroides Kunth, Enum. Pl. 2: 348. 1837. Type: Brazilia meridionalis (Es pîrito Santo: Vitöria), Sellow (B, photo in NY). --- Schizolepis olyroides (Kunth) Nees in Martius, FI. Brasil. 2(1): 187. 1842.

Schizolepis trigonocarpa Nees in Martius, Fl. Brasi1. 2(1): 186, t. 26. 1842. Type: Brasil, "in sylvis prov. Maragnaniensis et Paraensis," Martius (n.v., reported in BR). --- Scleria trigonocarpa (Nees) Steudel, Syn. Pl. Glumac. 2: 171.1855.

[Schizolepis rufescens Schrader ex Nees in Martius, F1. Brasil. 2(1): 187.1842. Nom. invalidum ex syn.]

[Schizolepis flagellum Sprengel ex Nees in Martius, F1. Brasi1. 2(1): 187.1842. Nom. invalid. ex syn.J

Scleria grandifolía Miquel, Linnaea 19: 230. 1847. Type: Brasil, Pará, Osembo, Focke (n. v.).

[Scleria kappleriana Hochstetter ex Steudel, Syn. P1. Glumac. 2: 172. 1855. Nom. invalid. ex syn.]

Scleria loefgreniana Boeckeler, Vidensk. Meddel. Kjøbenhvn. 1894: 240. 1895. Type: Brasil, São Paulo, Fazenda Campo Grande, Edwall 1977 (C).

Scleria lacunosa Boeckeler, Allg. Bot. Zeitschr. 2: 160. 1896. Type from "India occid."Hb. Krug et Urban. (B, photo in NY).

Distribution. Widely distributed in tropical America, from Guatemala and the 
Antilies southwards to northern Argentina. Shaded forest floors, but often seen also in forest margins and forest clearings.

Upon examination of type and other historic collections, supplemented by several type photos, I agree with Core (1936) that a number of very similar species, including S. cyanocarpa Kunth, S. sylvestris Kunth, S. trigonocarpa Nees and Boeckeler, are taxonomically identical with S. arundinacea. Core (1936), however, recognized $S$. arundinacea as specifically distinct from 5 . latifolia, because the former has purple inflorescence axes, branches, floral glumes and achenes, while $s$. latifolia has stramineous-brownish inflorescences and whitish achenes. While examining over 340 specimens of the $S$. arundinacea-latifolia complex from its total range, I noted that a number of plants with stramineous or brownish inflorescences bear purpie achenes or that plants with whitish achenes possess leaf sheaths stained reddish -purple in varying degrees. Furthermore, the purple coloring of the achenes varies from deep blackish-purple to light whitish-purple or to white, with no discontinuity between purple and white. In other respects, S. arundinacea and S. latifolia are morphologically identical and are found in the habitats of same ecological condition within the same range of geographical distribution. I regard $\mathbf{S}$. arundinacea as a mere color form of 5 . latifolia and consider it a synonym of the latter. Examination of the type of $\mathrm{S}$. lacunosa Boecklr. Shows that $i t$, too, is identical to $S$. latifolia.

As for 5 . olyroides Kunth, it has been considered distinct from $S$. arundinacea/ latifolia in having shorter leaf blades $(5 \mathrm{~cm}$ wide by less than $20 \mathrm{~cm}$ long $v 5.2$ to 5 $\mathrm{cm}$ wide by 45 to $60 \mathrm{~cm}$ long) in association with dense panicles. In my observation these distinctions are fictitious, since the leaves vary continuously from short oblong ones to linear-lanceolate ones with dimensions of 15 to $60 \mathrm{~cm}$ in length by 2 to $5 \mathrm{~cm}$ in width without showing any discontinuity. Whether the panicles are dense or lax shows no relationship with the size of leaf blades. For instance, two collections, Sucre et al. 5237 (NY, RB) from Rio de Janeiro and I rwin et al. 18295 (NY, UB) from D. F., Brazil, bear tightly clustered panicles less than $5 \mathrm{~cm}$ long hardly showing their short panicle branches but their linear-lanceolate leaves are up to $30 \mathrm{~cm}$ long. Ecologically, individuals of $\mathrm{S}$. latifolia having relatively short culms, short leaves, and small congested panicles occur in open habitats throughout the range of $s$. latifolia, and such short plants well agree with the characteristics of $s$. olyroides. In my opinion, therefore, 5 . olyroides is nothing but an ecotype of $S$. latifolia.

Within the highly variable and widespread Scleria arundinacea-latifolia complex, Schizolepis foliosa Nees, known also as Scleria plusiophylla Steudel, appears to be the only entity which can be segregated from the remaining plants by its tubercled achenes and pubescent leaves and culms (in contrast, $S$. latifolia has smooth achenes and glabrous leaves and culms). However, the pubescence on leaves and cuims with tubercle-based short hairs in Schizolepis foliosa varies from dense pubescence to almost none, resulting in intermediate conditions such as the combination of tubercled achenes and glabrous leaves and culms as in Irwin et al. 10911 (NY, UB) from Goiás. In 
Scleria, achenes with a tubercled surface can occur in species which normally possess smooth achenes. This is examplified by the common Scleria 1 ithosperma which usually has smooth achenes but includes subspecies roxburghiana with tubercled achenes. character does not warrant specific separation unless it is associated with other consistent characters. Since Schizolepis foliosa is identical to Scleria latifolia except for the usualiy pubescent leaves and culms and tubercled achenes, both of which are variable, 1 recognize Schizolepis foliosa only as a subspecies of

Scleria latifolia:

2b. subsp. foliosa (Nees) T. Koyama, comb. nov.

Schizolepis foliosa Nees in Martius, Fl. Brasil. 2(1): 188. 1842. Type: Brasil, "in Brasilia meridionali," Sellow (B, photo in NY). -- Scleria plusiophylla Steudel, Synops. Pl. Glumac. 2: 172. 1855. A new name for Schizolepis foliosa Nees because of Scleria foliosa Hochst. ex A. Richard, 1851.

Distribution. From central Brazil southwards to northern Argentina. Sedge on forest floors.

Specimens examined: BRAZ1L. Distrito Federal: Parque Municipal do Gama, $1150 \mathrm{~m}$, 1rwin et al. 10199 (NY, UB). Minas Gerais: Serra do Espinhaço, base of Serra da Pieda de, ca. $35 \mathrm{~km} E$ of Belo Horizonte, $1600 \mathrm{~m} \mathrm{alt.,} \mathrm{Irwin} \mathrm{et} \mathrm{al.} 30287$ (K, NY, UB); ca. $34 \mathrm{~km}$ E of Belo Horizonte, ca. $1500 \mathrm{~m}$ alt., I rwin et al. 30613 (K, NY, UB, US); Minas iwithout further details], Glaziou 18593 (P). Goiās: Serra Dourada, ca. $30 \mathrm{~km} \mathrm{SE} \mathrm{of}$ Goiàs Velho, $700 \mathrm{~m}$ ałt., Irwin et al. 11911 (NY, UB). Paraná: Rio Iguaçu, Salto Gran de, Hatschbach 13895 (MBM, NY); Rio Iguaçu, I km acima de Salto Osörio, Hatschbach 24178 (MBM, NY). PARAGUAY. Cordiliera Central, Cerros de Tabaty, Hassler 6365 (G, NY); Alto Paranä, Puerto Presidente Stroessner, at Km. 12, Casas \& Molero FC 3755 (NY). AR GENTINA. Corrientes: Depto. San Ignacio, Peñon Reina Victoria, Krapovickas E Cristöbal $28753(N Y, S I)$.

3. Scleria myricocarpa Kunth, Enum. P1. 2: 347. 1837. Type: "Brasilia Meridionalis, " Luschnath (B, photo in NY) ... Schizolepis myricocarpa (Kunth) Nees in Mart., F1. Bra sil. 2(1): 189. 1842 .

Schizolepis arguta Nees in Mart., Fl. Brasil. 2(1): 189. 1842. Type: Brazil. Sellow in Herb. Schrader (B, photo in NY).-- Scleria arguta (Nees) 5 teudel, Synops. Pl. Glumac. 2: 172, 1855.

[Scleria myricocarpa Kunth forma pallida Kunth ex Nees in Mart., Fl. Brasii. 2(1) : 189. 1842. Nom. invalidum ex syn.]

Scleria atropurpurea Boeckeler, Vidensk. Meddel. Kjøbenhvn 1879-80: 29. 1879. Type: Brazil: "in vicinia urbis Rio de Janeiro", Glazion 7989 (holotype C; isotype P). Scleria microstachya Boeckeler, Flora 63: 454. 1880. Type: "Brasiila," Sellow (B, $\mathrm{n} \cdot \mathrm{v} \cdot \mathrm{)}$

[Descr. emend. et amplif.] Rhizome knotty, horizontal, lignescent, the inter- 
nodes an ovoid-globose enlargement of culm-base, 8 - $12 \mathrm{~mm}$ wide by $10-12$ mm wide, clothed with red-brown scales. Culms loosely tufted or somewhat arranged in a row along the rhizome, 1 - $3 \mathrm{~m}$ tall, 3 - $5 \mathrm{~mm}$ wide below, 4-to 8-nodose, the internodes 5 - $30 \mathrm{~cm}$ long, acutely triquetrous with sharp (rarely somewhat wing-like) scabrous angles, the sides slightly concave, glabrous to hispid-pubescent. Basal 2 to 4 sheaths subaphyllous, tinged with red brown or red purple, winged except for the lowest portion. Leaf blades linear to broadly linear, $20-50 \mathrm{~cm}$ long, $10-25(-45)$ mm wide including wings, gradually attenuate to long-acuminate and serrulate-scabrous apex, herbaceous to subcoriaceous, glabrous and occasionally roughened above, often hispidulous to roughened on slightly whitish lower surface, 3-costate and many-veined, the wings $1-12 \mathrm{~mm}$ wide, ending at $5-17 \mathrm{~cm}$ below apex; sheaths shorter than the culm-internode, $7-20 \mathrm{~cm}$ long, hispid-pilose to glabrescent, greenish or tinged with red brown toward base, the orifice often densely pubescent, the wings $2-10 \mathrm{~mm}$ wide, deeply green, scabrous on margins, usually gradually widened upward and continuing to leaf blade as its flanged margins; contraligules deltoid, 4 - $8 \mathrm{~mm}$ long, glabrous to pubescent, often colored with red brown on margin, ciliate or glabrescent. Inflorescence with 2 or rarely 3 panicles, pale-stramineous to brown; panicles pyramidal, sublax, the terminal panicle $10-16 \mathrm{~cm}$ long, 5 - $10 \mathrm{~cm}$ wide, lateral panicles up to $7 \mathrm{~cm} l o n g$ by $5 \mathrm{~cm}$ wide; branches $1-7 \mathrm{~cm}$ long, patent, rather slender, once or in lower ones often twice further branched, the branchlets up to $2 \mathrm{~cm}$ long; axis, branches and branchlets sharply angular, glabrous to subdensely hispid-pubescent; leafy bract l or 2 , shorter than to surpassing the inflorescence; bracteoles scale-like, ca. $2 \mathrm{~mm} l o n g$, pilose or ciliate, the midvein occasionally forming a setaceous blade up to 3 mm long. Staminate and pistillate spikelets intermingled. Staminate spikelets sessile to shor -pedicellate, solitary or 2 or 3 approximate, oblong-eliptic to oblong-lanceolate 3 - $4.5 \mathrm{~mm}$ long, $1-1.5 \mathrm{~mm}$ wide, pale-green and slightly stramineous-tinged; glumes ovate, $1.5-2.5 \mathrm{~mm}$ long, puberulent, acute to mucronate at apex. Pistillate spikelets few, sessile, 3.5 - $4 \mathrm{~mm}$ long; glumes two, subtending achene and subequal, shorter to longer than the achene, broadly ovate, $2.5-3.5 \mathrm{~mm}$ long, 2 - $3 \mathrm{~mm}$ wide, membranous, pale-greenish and more or less red-purple on ciliolate margins, the apex acute. Achenes globose to weakly depressed-globose, $2.3-2.6 \mathrm{~mm}$ high and wide, rounded at base, rounded to rounded-truncate at mucronate apex, irregularly trabeculate-rugose, short-pubescent on ridges, beige to purplish-brown or beige and stained with purple above. Hypogynia brownish, 3-lobed, the cupular part $0.3 \mathrm{~mm}$ deep, the lobes broadly oval in outiine, $1.2-1.5 \mathrm{~mm}$ wide, $1.5-1.7 \mathrm{~mm} 1 \mathrm{long}$, deeply lacerate with 8 to 15 subulate teeth.

Distribution. Brazi and adjacent Bolivian Province of Beni. Tropical forests and campo grassiands, often on sandy soil.

BOLIVIA. Beni: $5 \mathrm{~km} \mathrm{NW}$ of Guayaramerin, Anderson 11833 (INPA, MICH, NY). BRA ZlL. Rondōnia: Rio dos Pacaás Novos, just above and below the first cachoeira, c. 220 $\mathrm{m}$ alt., Anderson 12277 (INPA, MG, MICH, NY); vic. of Santa Barbara, $15 \mathrm{~km} E \mathrm{kf}$. 117 
on Porto Velho-Cuiabä Highway, Prance \& Ramos 6888 (INPA, K, NY, US). Parä: Alto Tapa jös, Rio Cururu, $S$ of Missão Cururu, $150 \mathrm{~m}$ alt., Anderson 10700 (NY, UB) region of the village of Mouro, 2 hours by launch downstream for Missão Cururu, Anderson 11084 (NY, UB); region village of Pratati, 200-300 m alt., Anderson 10752 (UB, NY). Minas Gerais: Serra do Espinhaço, c. $27 \mathrm{~km}$ SW of Diamantina, $1300 \mathrm{~m}$, Irwin et al. 21982 (UB, NY); Vi çosa, Agricultural College Land, $675 \mathrm{~m}$ alt., Mexia 4825 \& 5145 (NY, US). Rio de Janei ro: Petröpolis, 2,-3,000 ft., Ball in 1882 (NY); I tatiaya, $1200 \mathrm{~m}, 0$. Kuntze 67 (NY).

In my opinion Kunth (1837) is correct in assuming that Scleria arguta is merely a color form 5 . myricocarpa, distinguishable from the former only in the pale -stramineous spikelets instead of brown to reddish-brown ones. Although Nees claims that 5 . myricocarpa differs from $S$. arguta in the "spicis purpurascentibus ...., spicis masculis paulio majoribus ...," and in the "fructu etiam majori," I failed to see any such differences at all. The color of the spikelets varies from pale greenish through straw color to purplish-brown with intermediate stages of greenish glumes with margins variously colored with red purple or purplish-brown. I can find no difference in size of achenes and staminate spikelets between the plants bearing pale greenish spikelets and those with purplish or brownish spikelets. The degree of pubescence on leaves and culms also varies greatly. Plants from western Brazi i ian Amazonia and adjacent Bolivia tend to have noticeably broader leaves and paler inflorescences than those fron eastern and southeastern Brazil.

4. Scleria mitis Bergius, Kongl. Vet. Akad. Hand1. Stockholm 26: 145, t. 5, 1765. Type: "Habitat in Surinamo."

4a. subsp. mitis -- Carex mitis (Bergius) Gmelin, Syst. Nat. 2: 138, 1791. Ophryoscleria mitis (Bergius) Nees in Martius, Fl. Brasil. 2(1): 183. 1842.

Scleria riparia Poepp. E Kunth ex Kunth, Enum. Pi. 2: 341. 1837. Type: Prope Tocache, Mission del Huallaga, Poeppig $\$ . n$. (B; photo in NY). --- Ophryoscleria riparia (Poepp. E Kunth) Nees in Martius, Fl. Brasil. 2(1): 184. 1842.

[Scleria latifolia Reichenb. ex Nees in Martius, F1. Brasil. 2(1): 183. 1842. Nom. invalid. ex 5yn]

Ophryoscleria lucida Nees in Martius, Fl. Brasil. 2(1): 183, t. 25. 1842. Syntype: Brasil, Minas Gerais, in campis altis do Paranan, Martius (M, lectotype chosen here); in sylvia S. Pauli et Rio de Janeiro, Martius (M); Gujana, Weigelt (n.v., reportedly in BR) --- Scleria lucida (Nees) Steudel, Synops. Pi. Glumac. 2: 168. 1855.

[Scleria praealta Salzmann ex Schlechter, Bot. Zeit. 3: 461. 1845. Nom. invalidum ex syn.]

[Scleria trialata Bertero ex Boeck/r., Linnaea 38: 521. 1874. Nom. invalidum ex syn. ]

Scleria trinitatis Boeckeler, Cyper. Nov. 2: 31. 1890. Type from Trinidad (n.v.). 
Distribution. Widely distributed in Tropical America, from Guatemala and Cuba southwards to Ecuador and Brazilian Amazonia. Swampy ground along rivers or lagoons and in swamp forests.

Scleria eggersiana Boecklr. closely resembles S. mitis Bergius. In his key, Core (1936) segregated it from the latter primalily in its stylebase, which is "brown and rather early deciduous" in contrast to the "black" and "usually persistent" one in the latter. Studying nearly all of the specimens that were annotated by Dr. Core as S, eggersiana and $\mathrm{S}$. mitis, I am unable to distinguish his 'brown" stylebases from his "black" ones. The caducity of stylebases appear to be more reliable than the color, yet this characteristic does not make a clearcut separation between the two species, for many exceptions occur. Some specimens determined by Core as S. mitis (e.g., Maguire 23903 from Venezuela and killip 44030 from Cuba) show caducous styiebases, while other collections determined by him as S. eggersiana (e.g., Britton 10274 from Cuba and Nash 324 from $\mathrm{Haiti)}$ show stylebases that are clearly persistent.

My observation on the ample collections of the S. mitis-eggersiana complexcited here revealed that the two taxa are generally separableby the combination of characters shown in the table below:

Table 1. Comparison of characteristics in the 5. mitis-eggersiana complex.

\section{S. mitis}

Inflorescences: $\quad$ Stiffly erect, $40-70 \mathrm{~cm}$ by $5-9$ cm; panicle branches patent, as long as $7 \mathrm{~cm}$.

Leafy bracts: Longer ones much surpassing the inflorescence.

Achenes:

Ovoid-globose, $2.0-2.5 \mathrm{~mm}$ long and as wide, rounded at apex, white to greyish.

Style-bases:

Conical minutely retrorsely hispidulous $1-1.2 \mathrm{~min}$ long, $0.7-1$ mm wide at very base.

Floral giumes: Brownish-greenish.

\section{S. eggersiana}

Often somewhat inclined above, $25-40 \mathrm{~cm}$ by $3-5 \mathrm{~cm}$; panicie branches suberect, as long as $4 \mathrm{~cm}$.

None exceeding the inflorescence, the longer ones reaching only $1 / 2$ to $1 / 4$ way below the apex of the inflorescence.

Broadiy ellipsoid to globose, 2.2-3 mm by $2.2-2.75 \mathrm{~mm}$, rounded -oblate at apex, cream - white to grey-brown.

Subulate-conical, glabrous or very minutely antrorsely his pidulous, 0.5-0.7 nm long, $0.3-0.5 \mathrm{~mm}$ wide at very base.

Stramineous with dense red -brown flecks.

All these characteristics, however, may sometimes be intermediate. Wurdack 290 (NY) from Deita Amacuro, Venezuela, for instance, shows the vegetative features of $\mathrm{S}$. eggersiana and the achene characters of $\mathbf{S}$. mitis. Its grass-green leaves, shorter 
bracts, straw-brown floral glumes and slightly inclined panicles are typical of S.

eggersiana, but its conicai, retrorsely pubescent stylebases and well-developed side branches of the panicles are definitely characteristic of $S$. mitis.

S. mitis tends to occur more frequently in the Andean regions, whereas the center of distribution of $\mathbf{S}$. eggersiana is seen in the Amazonian basin. These however, coexist throughout their ranges, spreading from Central America and two, Cuba southwards to Paraguay with no clear ecological or geographical separation. 1 concluded that the two taxa are recognizable, but at the subspecific level anly, and accordingly 1 relegate $S$. eggersiana as a subspecies of $S$. mitis as follows:

4b. subsp. eggersiana (Baeckeler) T. Koyama, comb. nov.

Scleria eggersiana Boeckeler, Cyp. Nov. 2: 41. 1890. Type: Insula Cuba,

Eggers s.n. (B, photo in NY).

Scleria griesebachi i C.B. Clarke in Urban, Symb. Antill. 2(1): 150. 1900. Syntype. Jamaica, W. Wright (K); Puerto Rico. Eggers 432b (B) \& 671 (B); Puerto Rico, prope Adjuntas ad margines sylvae montis Cedro, Sintenis 4279 (B. PR): Antigua, Nicholson (n.v.); Guadeloupe, Husnot 43 (K, P); Dominica, Imray 352 (n.v.); Martinique, Duss 445 (K, NY, P).

Scleriamitis sensu Griseb., Fl. Brit. West Ind. Isl. 678. 1864. non Bergius.

Scleria microcarpa sensu Griseb., Cat. P1. Cuba 248. 1866, pro minore parte, quoad "Cuba Wright 723b et 724a" tantum, non Nees.

Scleria mitis Bergius var. atro-brunnea Kükenthal in Fedde, Repert. Sp. Nov.

219. 1926. Type: Cuba, Pinar del Rio, Ekman 16656 (B, S).

5. Scleria cerradicola T. Koyama, sp. nov. distincta e sectione Hymenolytro. A S. cyperinoide habitu multo minore, panicula dimidio breviore sublaxaet achaenio longiore albescenti fere laevi non purpureo-nigrescenti neque undulato-tuberoso conspicue differt. Fig. 1 .

Rhizoma lignescens, horizontaliter repens, internodi is ovoideo-globosis $5-10$ mm longis ac latis gangli iforme, squamis purpureorbrunneis castaneisve cinctum. Culmi erecti, subrigidi, $30-60(-80) \mathrm{cm}$ alti, 4-6-nodosi, internodiis (3-) $5-14$ longis $1.5-2.5 \mathrm{~mm}$ latis triquetris virentibus vel rufo-brunneo-suffusis exsertis scatrangulis. Vaginae basilares 2 vel 3 elaminatae, rubro-brunneae, oblique secto. Foliorum laminae lineares 7 - $37 \mathrm{~cm}$ longae, 4 - 7 mm latae, 3-costatae, costa subtus marginibusque retroversim scabrae, apicem versus sensim attenuatae, apice acutae; contraligulae adpresse rotundae vel subdeltoideae, 2 - 4 mm longae, rubro - brunneo-tinctae, auricula membranacea late ovata brunnea 4 - 8 mm longa 5 - 7 mm lata latissime marginatae; foliorum vaginae laeves, 7 - 12 cn longae, glauco-virides, sub ore et basin versus rubro-brunneo-tinctae, trialatae, alis $1.5-3$ mm latis viridibus margine scabris apicem vaginae desinentibus. Panicula solitaria, ovoideo-ellipsoidea, 3 - $6 \mathrm{~cm}$ longa, 2 - $3 \mathrm{~cm}$ lata, sublaxa, composita et tantum parte basilare plus minus 


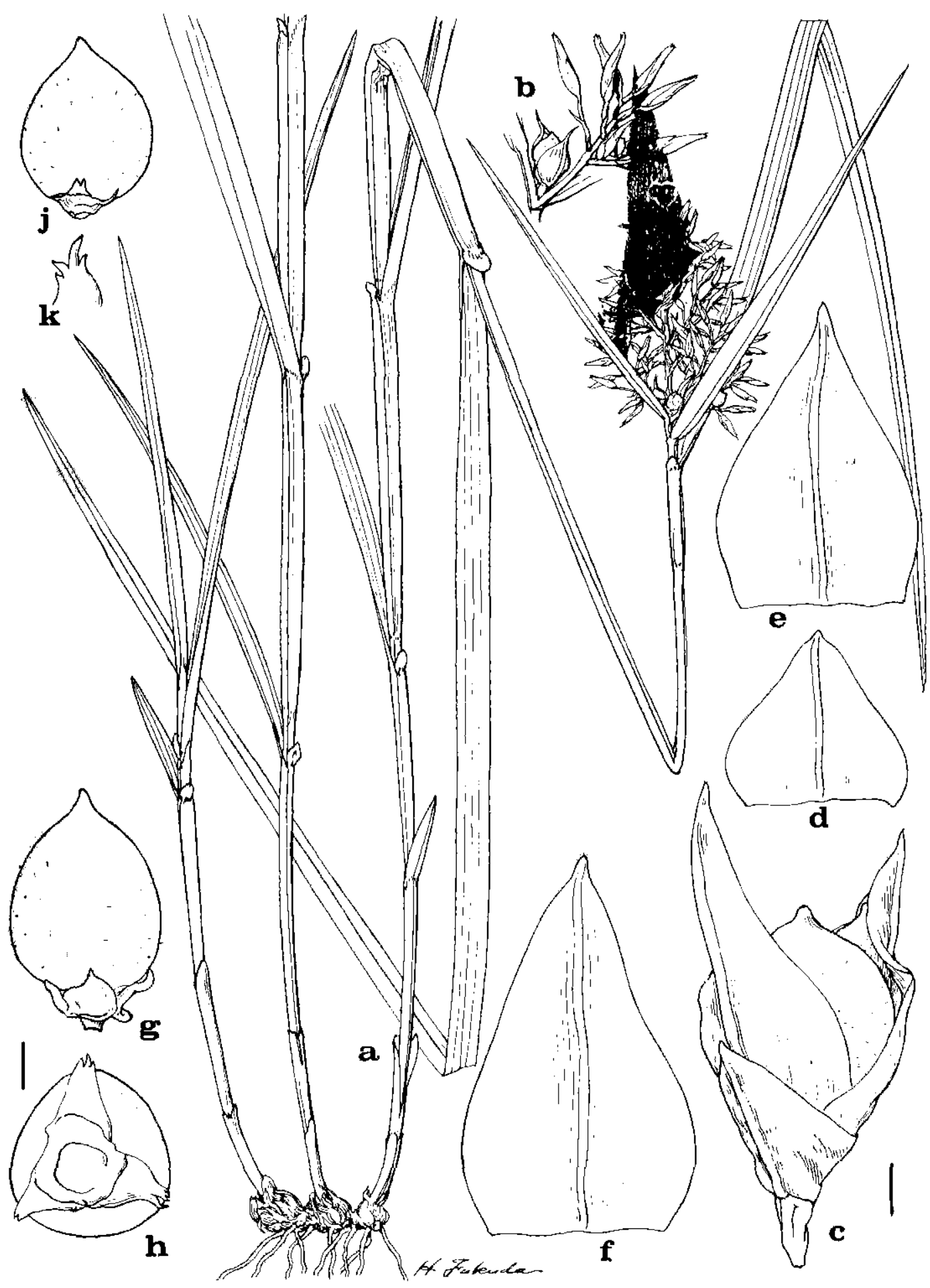

Fig. 1. Scleria cerradicola T. Koyama: a. Habit; b. Bisexual inflorescence branch from lower part of panicle; c. Pistillate spikelet; d, e \& f. Pistillate glumes; $g$. Lateral view of achene with hypogynium; h. Hypogynium with achene viewed from bottom; $j$. Achene with hypogynium; k. Hypogynium lobe. (a-h, Anderson 8724; j\& k, Goodland 830.) Bar scale $=1 \mathrm{~mm}$. Drawn by H. Fukuda.

Cyperaceae of tropical ...

INSTITUTO NACIONAL DE PESQU1SAS DA AMAZONIA 
decomposita; axis polygonus, hispidulus; rami patentes, 1 - 2 cm longi, subdense hispiduli, inferiores bisexuales, basi spicula unica sessile adjecti, sursum spiculis masculis 2 - 6 pedicellatis ramosi, superiores tantum masculi; bracteae 2 vel foliaceae, non vaginantes, ima $10-20 \mathrm{~cm}$ longa; bractea superiores et bracteolae setaceae, $4-7 \mathrm{~mm}$ longae. Spiculae foemineae sessiles, 7 - 10 mm longae; glumae late ovatae, apice acuminatae vel cuspidatae, 1-costatae, tenuiter chartaceae, pallide virentes, margine membranaceae fulvescentes, ima 3 - $4 \mathrm{~mm}$ longa, secunda ca. $7 \mathrm{~mm}$ longa, tertia 8 - $9 \mathrm{~mm}$ longa. Spiculae masculae breviter ( 1 - $4 \mathrm{~mm}$ ) pedicellatae, lanceolatae, 5 - $6 \mathrm{~mm}$ longae, 1 - $1.5 \mathrm{~mm}$ crassae, brunneae, distiche pluriflorae; glumae oblongo - lanceolatae, apice acuticusculae obtusius-culaeve, mucronatae. Achaenia late ovoidea, subteretia, 3.2 - $4 \mathrm{~mm}$ longa, 2.8 - $3.6 \mathrm{~mm}$ late, alba vel albescentia nunquam griseo -purpureo-tincta, sublaevía vel minute puberula, non tuberculata nec rugosa, bas i truncato-contracta, apice mucronata; hypogynia pallida, profunde trilobata; lobi ovato -deltoidei pallidi 1.4 - $2 \mathrm{~mm}$ longi, apice vadose 2 - 4-laciniati vel dentati.

Type: BRASIL. Mato Grosso do Sul: cerrado along road between Bataguaçu and Figeira, in thickets, T. Koyama E E. de Lima 13733 (SP holotype, isotype NY).

Distribution. Central and northern Brazil and adjoining Venezuelan Amazonas and southern Guayana. Shallow dry soil in campo grasslands and thickets as well as in sandy soil over quartzite and crystalline rock formations.

Specimens examined, VENEzUELA. Amazonas: vic. of Santa Bärbara del Orinoco, Berry 544 (NY). GUAYANA. Rupununi Northern Savanna, between Naja and Ikuwalli Creek, $350 \mathrm{ft}$. alt., Goodland 830 (NY); Orinduik, Daris 733 (BRG, K, NY). BRAZIL. Maranhão: Mun. de Balsas, ca. $25 \mathrm{~km}$ NNE of Balsas. $250 \mathrm{~m}$ alt., Eiten E Eiten 3642 (NY, SP, UB); c. $45 \mathrm{~km}$ SSE of Loreto, Eiten $\varepsilon$ Eiten 10653 (NY, SP). Goiäs: north side of Paraiso do Norte de Goiäs, $390 \mathrm{~m}$ alt., Eiten E Eiten 10077 (NY, SP); Chapada dos Veadeiros, 24 $\mathrm{km} \mathrm{S}$ of Terezina, $1250 \mathrm{~m}$ alt., Anderson 7194 (NY, UB); Serra dos Cristais, $25 \mathrm{~km} S \mathrm{~S}$ Cristalina, $1150 \mathrm{~m}$ alt., Irwin et al. 13842 (NY, UB). Bahia: drainage of Rio Corren te, Rio Piau, c. $225 \mathrm{~km}$ SW of Barreiras on road to Posse, $850 \mathrm{~m} \mathrm{alt.,} \mathrm{Irwin} \mathrm{et} \mathrm{al.}$ 14682 (NY, UB); Serra do Curral Feio, $16 \mathrm{~km}$ NW of Lagoinha on 5 ide road to Minas do Mimoso, 950-1000 malt., Harjey 17023 (K, NY). Minas Gerais: Serra do Espinhaço, 25 $\mathrm{km}$ NE of Diamantina, c. $1.5 \mathrm{~km}$ from Rio Jequiti, 790-900 m alt., Anderson 8724 (1AN, NY, UB). Mato Gros5o: road betw. Campo Grande and Cuiabā, Mun. Camapuã, Hatschbach 31900 (MBM, NY); drainage of Upper Rio Araguaia, summit of Serra Azul, c. $75 \mathrm{~km} 5$ of Xavantina, 600 m alt., I rwin et al. 17230 (NY, UB); Mato Grosso do Sul: Mun. Batagua ६̧u, along Road BR-267, Hatschbach 24260 (MBM, NY).

Scleria cerradicola ( $\mathrm{Fig}$. 1) stands distinct among the confusing members of the section Hymenolytrum in its smaller habit, narrower and shorter leaves, and smaller, essentially compound (not decompound) panicles. In this species the panicles are rather lax and their branches are simple except for the basal one or two, which tend to branch again, while in the remaining species of the section, the much larger and more crowded panicles have many branches borne in the lower and the middle portions, 
which are twice or sometimes thrice further branched and, kence, the paricles essentially decompound. The narrowly ovate disc-lobes with finely laciniate apices seen in this species recali those of $S$. cyperinoides. The latter species, however, differs amply from $S$. cerradicola in its smaller, ver ruculose-rugulose, and purplish -greyish achenes besides having much larger panicles and vegetative parts.

RESUMO

São discutidas a taxonomia do complexo Scleria arundinacea-latifolia, e das es pécies S. mitis e. S. myhicocarpa, todas taxa de parentesco controvertido e com distri bruiçäo arpla nos neotrōpicos. Sclenia cerradicola $\vec{e}$ descrita como nova, na secçä Hymenolytrum, e uma ampliação na distribuiça geggrälica de scleria neogranatensis, uma espécie rara, $\bar{e}$ notada.

\section{References}

Core, E. L. 1936. The American species of Scleria. Brittonia 2: 1-105, p1s. 1-3. Royama, T. 1969. The Cyperaceae of Tropical America. Some New or Critical Species.

[I ]. Japan. J. Bot. 20: 123-134.

II. Bot. Mag. Tokyo $97: 413-421$. Kunth, C. S. 1837. Enumoratio Plantarum 2: 1-128. Stuttgart.

Nees, Von Esenbeck, C. G. 1842. Cyperaceae. In: Martius, F1. Brasi1. 2(1): $1-226$, 